\title{
Две српске песме из Белог Тимока о сахрањивању јунака у гори
}

\author{
Зоја Карановић
}

У спомен на брата Станка

Предмет овог рада је драгоцени запис две варијанте српске народне песме које је ауторка, заједно са Весном Ђукић, забележила у селу Ошљане у Белом Тимоку 1997. године. Песма се у раду доводи у везу с аналогним тематско-мотивским и садржинским варијантама са ширег терена источне и југоисточне Србије, на којем се оне могу пратити током 20. века. Постоје и нотни записи песме, а о њеној популарности данас говоре и мелодијски снимци на интернету. Значајни трагови живота песме указују на некада велико богатство српске усмене песничке традиције на испитиваном терену. Они сведоче и о њеној жанровској и поетичкој динамичности и флексибилности и, посебно, неотуђивости од српске народне поезије у целини.

Кључне речи: српске народне јуначке песме, Бели Тимок, смрт у гори, гроб у гори, теренска бележења, процес дехероизације, деепизација

Ауторка овог рада боравила је на терену, заједно са Весном Ђукић, у делу Тимочке Крајине у селима око Белог Тимока ${ }^{1}$, у неколико наврата 1997. и 1998, кад је забележено преко 250 српских народних песама, које се у облику књиге припремају за штампу. Касније, 2014,2015 . и 2016, радила је на истом терену с групом колега и студената чије истраживање је организовала и предводила. Намера је тада била да се, поред осталог, провере раније сачињени записи и, евентуално, пронађу нове, још живе песме. ${ }^{2}$ Показало се, међутим, да већина

\footnotetext{
1 Теренска истраживања обављана су у селима: Боровац, Бучје, Валевац, Врбица, Витковац, Дебелица, Дреновац, Јаковац, Јелашница, Кожељ, Мариновац, Мали Извор, Ново Корито, Ошљане, Петруша, Потркање, Равна, Селачко, Трновац.

${ }^{2}$ Напомињем да се рад на терену одвијао без сондирања и помоћи локалних власти или мештана, методом случајног одабира саговорника, као и да није био финанси-
} 
ранијих казивачица више није међу нама ${ }^{3}$, док се оне са којима су разговори у новије време вођени углавном више нису сећале песама. ${ }^{4}$

У поменутој збирци из Белог Тимока, поред осталих, налазе се две варијанте песме (в. Прилог) с познатом темом смрти и сахрањивања јунака у гори (в. и: Детелић 1992: 57-88; Детелић 2013: 99-118). И оне у основи представљају кратке рефлексије ових сижеа, мотива и садржаја популарних у јуначкој епици, а мање су њихове праве херојске авантуре, на које се ипак наслањају у значајним реминисценцијама. ${ }^{5}$ Намера је да се ова претпоставка у раду провери и, евентуално, потврди постојање епике и јуначког погледа на свет на простору који је предмет испитивања у овом раду.

Записи поменутих песама забележени су 30. априла 1997. у селу Ошљане од две казивачице - Љубице Ђорђевић ${ }^{6}$ и Љубице Пујић ${ }^{7}$, што потврђује да је песма на испитиваном терену још живела крајем прошлог века (макар у сећању појединих људи). Њени аналогни регионални варијантни записи ${ }^{8}$, који даље потврђују распрострањеност ове песме, могу се, међутим, пратити још од почетка прошлог века. А

ран од било које државне или невладине организације. Разговори су у првом наврату снимани касетофоном, касније диктафоном, кад је било могуће. Разговори су иначе вођени уз пуну усмену сагласност и у доброј вољи казивача, на чему им захваљујемо.

${ }^{3}$ Нека почивају у миру.

${ }^{4}$ Свим нашим живим казивачицама овога пута топло захваљујем. Такође захваљујем колегиницама и студентима на уложеном напору да оживе сећања казивача.

${ }^{5}$ Под јуначком песмом у најопштијем смислу овде се подразумева прича о борбама међу племенима, нацијама, припадницима различитих конфесија, чији репрезенти могу бити појединачни јунаци, групе, војске. Прича је, при том, уоквирена у историјско (псеудоисторијско) време и везује се за историјске (псеудоисторијске) догађаје и јунаке, који се боре против непријатеља властитом снагом, оружјем и сналажљивошћу, при чему у њима није искључено присуство митског кода. О овоме више в.: Мелетинский 1986.

${ }^{6}$ Љубица Ђорђевић рођена је 1920. године и није више међу нама. Била је писмена и завршила је четири разреда основне школе.

7 Љубица Пујић рођена је 1920. године и није више међу нама. Била је писмена и завршила је четири разреда основне школе. Мелодијски запис песме од ње је, према писаној информацији Светлане Спајић, сачинио Дејан Крстић (не зна се када). Такође према писаној информацији Светлане Спајић, којој захваљујем на подацима, она је казивачицу упознала 2004. о чему у писму, које ми је уступила Јелена Јовановић, каже: „Кад сам ја упознала Љубицу, 2004, већ је била потпуно без моћи говора и једва се кретала." Светлана Спајић, заједно са Боканом Станковићем, снимила је песму 2017. године, која сведочи о савременим начинима и условима живота елемената традицијске културе (песма је доступна на: https://www.youtube.com/ watch?v=C1 cwJLGJYR4).

${ }^{8}$ У раду су представљени варијантни записи испитиване песме, познати ауторки текста. Они су довољни за илустрацију процеса о којима се говори, а овде се не претендује на њихову исцрпност и коначност. 
најстарије бележење из југоисточне Србије, према сведочењу записивача, јесте песма певана на биљани петак (Грбић 1909: 55-56; Грбић 1966: 51) - дакле била је обредно кодирана и, по свему судећи, реплицира фрагмент иницијације. Од половине прошлог века ова песма је позната и у мелодијским записима (нпр. Манојловић [1949]1953: бр. 187 и 188). А о њеној популарности данас говоре и снимци на интернету.

И док се краћа варијанта песме из Белог Тимока своди на неколико уводних стихова о смрти и последњој вољи умирућег, с развијенијом молбом о томе где и како да буде сахрањен (казивање Љубице Ђорђевић), дужа песма описује околности које доводе до погибељи (насилна смрт јунака), овако: киша пада, јунаци/путнищи, сви осим Гојка, савијају барјаке да им не покисну. А он на упозорење осталих одговара:

„Нека ћисне, пуст да га остане!

Имао сам девет мила брата,

Сви су девет под њег' пођинули, И мен' пише, и ја да пођинем.“

Таман Гојко тој изрече,

Пуче пушка из гору зелену,

Па погоди Гојко барјактара.

Мртва глава, језик проговара:

„Над главом ми бунар ископајте,

Око бунар цвеће посадете,

Око цвеће клупе наместете.

Кад се врати војска са Косово,

Ко је жедан, воду да си пије,

Ко је млађан, цвеће да се кити,

Куј је рањен, клупе да си седне.“

(казивала Љубица Пујић)

Промицање јунака у пејсажу, те изненадна промена временских прилика које иначе наговештавају и сваку другу промену (што је општа карактеристика поетике усменог певања код нас), покретач су радње и њена мотивација. Иста промена симболизује живот и сучељавање са смрћу (кретање и заустављање), коју путници/јунаци, својим дискретним проласком кроз гору, настоје да предупреде, сви осим једног, Гојка. Он се ширењем барјака (што је и својеврсни херојски чин) имплицитно супротставља невидљивом непријатељу и последично предсказује и изазива сопствену смрт: „Пуче пушка из гору зелену, ${ }^{9}$ Па погоди Гојко барјактара“.

\footnotetext{
${ }^{9}$ Стих иначе представља формулу која се у српској песничкој традицији, у песмама различите садржине и различитих ситуација извођења, односно жанровске
} 
Метонимијски исказ постварености непријатеља ${ }^{10}$ који делује искључиво преко оружја, насупрот путницима - јунацима, интензивира страх и замагљује мотиве несреће који остају за песмом. У складу с тим је и његово физичко одсуство - непријатељ делује из заседе, невидљив ${ }^{11}$ и безимен, без обележја вере и народности, и зато је страшнији. И тако на фону демонског простора горе и сам постаје демонски маркиран, будући да демони управо у гори и обитавају, да је она њихово станиште (в. нпр. Иванов и Топоров 1965: 173; Детелић 1992: 59-67). А сама садржина песме везује се и за прастара исходишта епике која се утемељују у митском виђењу света. ${ }^{12}$

Насупрот скривеном непријатељу, на фону горе је поворка путни$\kappa a /$ јнака, представљена лапидарном констатацијом о њеном кретању: „Ћиша пада, путници путују“. Мотиви проласка поред горе или кроз њу и њену дивљину ${ }^{13}$, те начин на који се кретање одвија, међутим, непознати су. Упадљиво је такође одсуство коња и оружја, јуначких атрибута прве врсте $\mathrm{e}^{14}$, чиме је индикован повратак из боја поражених ратника, обележених и нехеројским атрибутом путници, мада се

провенијенције, варира, нпр.: „Пуче пушка из горице црне“ (Станковић 1951: бр. 86); „Пуче пушка из зелена луга“ (Станковић 1951: бр. 52; Симчевић 2014: бр. 157 и 158), „Пуче пушка чак са Копаника“; „Пуче пушка из града Козника“ (Симчевић 2014: бр. 1099 и 1100). Буком, односно звучним сигналима се у традицијској култури наговештава нека важна промена (Lič 1982: 94-96), као у варијантама ове песме, где пуцањ означава, смрт или свадбу.

${ }^{10}$ Под овим се подразумева деловање непријатеља преко предмета, у овом случају пушке.

${ }^{11}$ У прастаром поимању света код Словена и смрт је невидљива (Иванов и Топоров 1965: 71).

${ }^{12}$ Рани облици епике свакако исходе из митског погледа на свет, о чему детаљно говори, на пример, Мелетински (Мелетинский 1986: 62-78). Без митолошких елемената епска поезија се не може замислити (Чајкановић 1994б: 507).

${ }^{13}$ Шума/гора/планина у словенској традицији превасходно је супротстављена дому и, за разлику од дома, семантизује туђи свет, свет мртвих (Иванов и Топоров 1965: 168-175).

${ }^{14}$ Коњ и оружје су били знаци јуначког положаја прве врсте, његовог старешинства и части, о чему постоје и историјски извори. Краљ Милутин је, на пример, кад је предавао престо брату, предао му и „коња свога и оружје своје“ (Данило II, према: Ђорђевић 1984а: 103-108). Рефлекс у народној поезији налази се у песми о деоби Јакшића: „Дмитар иште коња старјешинство“ (Караџић 1845: бр. 98). Кобне последице раздвајања јунака од коња и оружја показују још записи бугарштица: о Радосаву Сиверинцу и Влатку Удинском (Богишић 1878: бр. 49); Девојка и Шишман (Хекторовић, према Пантић 1964: 50), затим и записи десетерачке поезије. А и Марко Краљевић по предању гине пошто му се Шарац заглави у бари (Караџић 1852: 345-346). О овоме види и: Крњевић 1986: 203. 
оружје и коњ могу јавити, и јављају се, у другим варијантама ове пес$\mathrm{Me}^{15}$, што, с друге стране, сведочи о њеној јуначкој утемељености.

Повратак из претпостављеног боја, у наставку, потврђује и довођење у везу с косовским јунацима, у тестаментарној молби умирућег да му на гробу ископају бунар, тако да повратници могу тамо да предахну и напију се: „Кад се врати војска са Косово / Ко је жедан, воду да си пије“, што се на крају и дешава.

Да ово није случајна интерполација једне казивачице, већ да је заиста постојала веза поменутог певања с косовском традицијом, показује и варијанта забележена око тридесет пет година раније у селу Врбица, од Ошљана удаљено једва нешто више од 10 км. У тој песми истоимени јунак, Гојко барјактар, за разлику од претходне, с војском/дружином лоциран је у стварни и митски простор Косова, у стиховима:

Поврвела војска на Косово,

Најнапред је Гојко барјактар:

Ударила тија роса,

Сви јунаци барјаци увише,

Гојко нече барјак да увије,

(Првуловић, Првановић, Јеремић 1962: 41). ${ }^{16}$

Сходно контекстуалним асоцијацијама које се покрећу у обе песме, актери се могу даље довести у везу и с Бошком Југовићем, преко познатих стихова Вукове песме (Караџић 1845: бр. 45). А будући да барјактар још од средњег века фактички представља угледног рат-

${ }^{15}$ На пример у другој варијанти из Ошљана, у стиховима:

Поред пута гробље ископајте,

Уз главу ми копље прибодете,

И на копље цвеће наредете.

Или у песмама из околине Власотинца:

Пободете му крстата барјака

Вржете му коња за јелу зелену

Дан да једе, два да жалеје.

(Младеновић 2010: забележено 1976, село Пржоње)

Па ископајте гроба мегданију

Побете ми четири до пет крстача

Вржете ми коња на крстачу

Дан да једе, три да болује.

Ставите му траву чемерику

Да жалеје Ђуру арамбашу.

(Младеновић 2010)

${ }^{16}$ Песма је забележена од Мирославе Живковић која је у то време имала 64 године. 
ника, те да се вековима сматрало да војска није поражена све док јој је стегоноша у животу, односно док се вије застава (у првом плану је њена заштита), јунак Гојко је, као и Бошко Југовић, репрезент херојског погледа на свет прве врсте.

Песма се с косовском митемом ${ }^{17}$ доводи у везу и у стиховима још једне варијанте:

Сви ајдуци барјаци завише,

Ајдук Ђура барјак не завива:

„Зави, Ђуро, крстата барјака,

Да не кисне свила и кадива.“

(Ђорђевић и Златановић 1990: бр. 391)

Барјак с крстовима је аналоган знамењу Бошка Југовића, као у стиху: „Крсташ му се по Косову вија“18 (Караџић 1845: бр. 45), будући да су хајдуци (о којима је овде углавном реч) такође носили такву ратну заставу ${ }^{19}$. О томе наведени стихови, реплицирајући стварност, и певају, што исказ кодира и хришћански и асоцира борбу против турских освајача, неверника, чиме је снажно обележена косовска митема. Јунак активира асоцијацију на Косово и поменом девет (варијантно осам) брата, исказом: „Нека ћисне, пуст да га остане! / Имао сам девет мила брата, / Сви су девет под њег' пођинули, / И мен' пише, и ја да пођинем.“ Гојко (и Првуловић, Првановић, Јеремић 1962: 41), или већ како му је име: Рада (Љубица Ђорђевић); Ђура барјактар (Ђорђевић 1958: 640-641; Симоновић 1988: бр. 174; Ђорођевић и Златановић 1990: бр. 391; Младеновић 2010: бр. 9, 10 и 11), Вељко барјактар (Симоновић 1988: бр. 104), Виден јунак (Симоновић 1988: бр. 176); Ран-

\footnotetext{
${ }^{17}$ Под појмом косовска митема овде се подразумевају веровања, причања, јунаци, хронотопи, реквизити, однос према свету итд. који у колективној свести активирају асоцијације на Косовску битку и догађаје везане за њу.

${ }^{18}$ Стихови с барјаком различито се у песми варирају: „Пред њима је Бошко Југовићу, / И он носи крсташа барјака“; „А ја ти се не бих повратио, / Ни из руке крсташ барјак дао, / Да ми царе поклони Крушевац.“

${ }^{19}$ Застава с крстовима код Срба прати се од Душана Силног. Димитрије Аврамовић је описао троугласту заставу од црвене свиле из Хиландара, у чијем се углу налазио крст. Постоје и спорадични подаци о косовској застави с крстовима, мада нема сигурних података о томе и мада се о косовском барјаку с крстовима певало (Васић 1979: 46-49; Костић 1960: 17-21). Има и предања о постојању застава с крстовима из овог периода (http://srbiubih.com/srednjovijekovne-srpske-zastave-zastava-pavlaorlovica/). Костић, према наводима Душана Поповића (Срби у Војводини II, 1959), доноси опис хајдучке заставе са крстовима: „Барјак чине платно и копље. Главни део барјака је платно, а главни знак барјака је крст, а не боја платна. Крст се стављао на платно, али и на копље, или на једно и на друго; стога се барјаци зову крсташи или крстати [...]. Барјаци су, изгледа, били од платна, често свилени, а обично у једној боји (зеленој, белој и др.)“ (Костић 1960: 33).
} 
ча буљубаша (Манојловић 1953: бр. 187 и бр. 188; Симоновић 1988: бр. 105; Ђурић 2006) - у наставку приче стварно и гине. А у моменту кад он сконча, будући да је једини актер с херојским атрибутом (мада не и с херојским, већ обичним народним именом), и дружина остаје без свог последњег јуначког обележја. Тако скончава не само актер са знамењем, већ узмиче и свака могућност за даље херојско деловање.

Колико је песма захваћена процесом дехероизације ${ }^{20}$ показује и чињеница да јунак гине од пушке, од оружја модерног доба ${ }^{21}$ које јунаци класичне епике ${ }^{22}$ не користе - они се углавном служе хладним оружјем и физичком снагом. Основу тог процеса „деградације“, наравно, не чини само коришћење ватреног оружја ${ }^{23}$ из заседе, већ и одсуство директног сукоба, боја, мегдана или јуначког подвига. При томе се и потреба за савијањем барјака експлицитно мотивише бригом да не покисне: „Сави', Гојко, барјак да не ћисне“, што је наравно штета, али и лош предзнак за актере и враћа збивање у митско-магијски код. Зато је овде, без обзира на све асоцијације на Косово, реч о два амалгамирана песничка времена: једно је аутентично херојско а друго је хајдучко, и оно је јуначко само делимично. Ипак, све то заједно

\footnotetext{
${ }^{20}$ Процес дехероизације одређује се према херојском/јуначком погледу на свет, који је у односу на њега носилац супротног предзнака, а херојски поглед на свет карактеристичан је за јуначку песму. Јуначка песма, пак, говори о различитим догађајима и актерима, углавном из историјске (квазиисторијске) и митске прошлости; јунаци су махом владари и феудалци који се боре против иноплемених, иноверних непријатеља углавном физичком снагом, храброшћу и хладним оружјем у различитим, али типолошки аналогним сукобима; они се боре за себе, своју заједницу, свога господара, штитећи своју земљу и своју веру од освајача и насилника (в.: Мелетинский 1986: 79-130). Зато је јуначка епика развила посебну поетику и етику коју пре свега одликују храброст, част и поштење њених јунака (в.: Мелетинский 1986: 79130). Сходно томе, под процесом дехероизације подразумева се све што је у песмама с јуначким темама (овде убиство хајдука из заседе) захваћено растакањем оваквог односа према свету. И то се овде показује анализама.

${ }^{21}$ Мускета се користи од 15. века, а класична пушка је у широј употреби од 19. века. О спорадичној употреби код нас казују налази, на пример, пушке „кукаче“ из 15. века у смедеревском граду, па се не искључује могућност да су се њима служили Срби приликом одбране тога града. А такве пушке нађене су и у средњовековном Купинову и Крушевцу (Васић 1979: 46).

22 За детаљније објашњење појма 'класична епика' в. Мелетинский 1986. Он разликује три њене историјско-типолошке фазе: рану, развијену или класичну и, коначно, позну (1986: 3-123).

${ }^{23} 0$ односу хероја према ватреном оружју у традицији сведочи и предање о Марку Краљевићу који је побегао у пећину кад је први пут видео пушку, рекавши: „Сад не помаже јунаштво, јер најгора рђа може убити најбољега јунака“ (Караџић 1852: 346). Будући, међутим, да је српска епика, за разлику од већине осталих активно живела дуго, она у песмама хајдучким, ускочким, песмама које певају о ослобођењу од Турака, као и овде испитиваној песми, обухвата и ватрено оружје.
} 
- живо сећање на кључни моменат српске средњовековне историје и оног што се уобичајено назива митизована историја, уклапајући се у колективно памћење - сведочи о важном трајању јуначке епике у времену, и то на матрици индивидуалног извођења једне потпуно анонимне жене из села с једва неколико десетина становника. И утолико је све ово, кад се постави на матрицу колективног памћења, важније.

Песма се, међутим, овим не завршава.У тренутку умирања „мртва глава, језик проговара“, јунак, након што је устрељен и истовремено оспособљен да види оно што долази са „друге стране“, изриче своју последњу вољу:

Над главом ми бунар ископајте,

Око бунар цвеће посадете,

Око цвеће клупе наместете.

Кад се врати војска са Косово

Ко је жедан, воду да си пије,

Ко је млађан, цвеће да се кити,

Куј је рањен, клупе да си седне.

Последња воља се односи, пре свега, на сахрањивање и уређење гроба ${ }^{24}$, а затим на војску која ће му походити гроб или ће проћи поред њега.

На гробу се прво, сходно жељи умирућег, а по матрици која се прати на целом српском културном простору, изводи вода (копа бунар), сади биље и, на крају, постављају клупе (в.: Детелић 2013б: 99-118). Ови поступци су некада практиковани како би се омогућио спокој умрлом који није скончао природном смрћу и не може бити сахрањен на гробљу (в. Зечевић 1982: 18; Детелић 1992: 74-76), а рефлекс је архаичне праксе из култа мртвих, у којем су вода, биље и клупе неизбежни елементи. ${ }^{25}$ Вода зато што на оном свету умрли у њој највише оскудева (Грбић 1909: 55-56; Зечевић 1982: 76-77) ${ }^{26}$, док је бунар симболички пролаз према оном свету (Валенцова, Виноградова 2001: 59; Детелић 2013а: 222-225), који покојнику обезбеђује и везу са живима. Биљке, односно дрвеће, цвеће, варијантно ружа, врба (Првуловић,

\footnotetext{
${ }^{24}$ Начин на који се уређује такав гроб део је култа мртвих (в.: Детелић 1992: 74-77; Детелић 2013б: 107-108). Старији слој певања, по свему судећи, представљају песме у којима растиње само ниче на гробовима умрлих (в.: Карановић 2006: 179-191). 25 Зато овај мотив није резервисан само за епику, него се прати и у лирским песмама и баладама (в.: Карановић 2009: 40-46).

${ }^{26}$ У доњем свету, према распрострањеним веровањима, влада жеђ па је важно да се мртвима обезбеди вода (Чајкановић 1994а: 332; в. и: Пешикан 2014: 15).
} 
Првановић, Јеремић 1962: 41) ${ }^{27}$ и босиљак (Симоновић, бр. 104) ${ }^{28}$, на гробу јунака који је погинуо под барјаком такође представљају растиње са хтонским обележјима ${ }^{29}$ и за њих се према веровању везује душа (Чајкановић 1994а: 338-340; Зечевић 1972: 70). Клупе су ту да обезбеде одмор пролазницима који ће поменути покојника, што је исказано и стиховима варијантних записа: „Кој да пројде, клупом да си седне, / Ноге да одмори, Ратку да спомене“ (варијанта Љубице Ђорђевић, Ошљане), што је својеврсна супституција одговарајућих ритуала (в.: Зечевић 1982: 78).

Други, тестаментарни део песме гради се, дакле, по устаљеном следу догађаја: молба - услишење, тако што јунак прво нешто тражи а затим се тражено испуњава, по обрасцу: речено - учињено. Јунакове жеље се остварују у последици онога што је на почетку предвидео ${ }^{30}$ и на крају пожелео. Збивање се одвија по моделу молба/заповест, остварење - најављено се, по датој схеми, одмах и реализује (в.: Schmaus 1971a: 61; Schmaus 1971b: 230, 234-237), односно све има магијске импликације.

Будући, међутим, да се збивања одвијају скоковито и великом брзином и да је песма захваћена процесом деепизације ${ }^{31}$, у њој су евидентне само последице поменутог начина сахрањивања и уређења гроба. У њима се манифестује и солидарност групе према појединцу ${ }^{32}$, што садржину песме везује за прастара социјална исходишта и супротставља је савременом виђењу света и човековој судбини усамљеника у њему. Јер комуникација ликова је ту заснована на „заједништву идеала, знања и интересовања, без којег нема праве епске поезије“ (Милошевић-Ђорђевић 1990: 107), и она је дубоко људска, па и данас измиче злонамерности актуелних злоделника. А присутна

\footnotetext{
${ }^{27}$ Врба се такође сади на гроб (Ђорђевић: 1984б: 234),односно хтонски је обележено дрво.

${ }^{28}$ М. Детелић, кад говори о уређењу гроба у гори, помиње: јабуку, ружу, лозу, бор и јелу (2010: 111-112), а овде се јавља и друго растиње са хтонским атрибутима.

${ }^{29}$ Све поменуте биљке погодне су да изразе амбивалентну позицију умрлих у граничном простору. О томе в.: Чајкановић 1994в: 39-40, 62, 179-180; Детелић 2008: 121-124; Карановић 2009: 19-48.

${ }^{30}$ Актер при томе зна своју судбину, за разлику од умирућег Марка Краљевића, на пример, што указује на динамичност живота епике.

${ }^{31}$ Под процесом деепизације подразумевам сажимање радње, тамо где се иначе очекује хронолошко причање догађаја с развијеним системом понављања.

32 Прописно сахрањивање је вршено како би душа пронашла мир (в. и: Детелић 2013: 103б), али није било обавезно: оно је „врста поступка са погинулима у планини (који могу остати и непогребени, као на бојном пољу), дар живих драгим покојницима, израз последње и највеће милоште“ (Детелић 2013: 112б).
} 
је свуда у усменој поезији на подручју где живе или су некада живели Срби.

Ништа од овог, међутим, није део експлицитног наратива већ се само подразумева ${ }^{33}$, будући да се фокус догађаја премешта са уређења гроба на његове последице:

Таман Гојко то изрече,

Ал' ето ти војска од Косово.

Ко је жедан, воду пио,

Ко је млађан, цвеће се китио,

Куј је рањен, клупе одморио.

Тако се збивање изнова рефокусира на јуначки код, упркос чињеници да се сама акција одвија у митском, обредном и етичком кључу, у изванвременској комуникацији живих са мртвима и оних који се спремају за умирање.

Специфичност ове варијанте у односу на остале записе даље је и фокусирање на завет умирућег/умрлог („мртва глава, језик проговара“), односно укључивање рефлексије на војску која се враћа са Косова, и богатство асоцијација које то укључује. Брига за повратнике изречена је у жељи да косовским јунацима омогући предах и да се олакшају муке рањеницима, као и да умирући у смрти буде повезан с њима. Ову жељу интензивира помен „девет мили брата“ јунакових (слично у запису из околине Бољевца, Грбић 1909: 55-56), који су раније погинули (а све то се догодило негде изван песме и овде је присутно само у реминисценцијама), чиме се херојско време растеже, а однос према Косову додатно сакрализује. И на овим линијама песма се такође не само чврсто везује за косовску митему, већ се природно уклапа у контекст шире српске традиције певања.

Усмереност ка гробу и његовом уређењу, која даје основни тон песми, уводи је и у контекст херојског ламента. То обележава и песме косовског циклуса у којима се такође пева о погинулим у боју, за њихов спомен, за душу (Пропаст царства Српскога, Косовка дјевојка), посебно ако се има на уму да је песма једним делом грађена техником исказа активног лица (,ја“ форма), која кореспондира с ламентирањем. И на овај начин се песма из Белог Тимока везује за аналогну општесрпску песничку традицију.

Даље, ова локална варијанта везује се за ширу општесрпску традицију и Вуковим записом из далеке прошлости с мотивом пушке која погађа барјактара у гори, упркос томе што је у њој реч о злом

\footnotetext{
${ }^{33}$ Будући да је брига о мртвима основни задатак живих припадника заједнице, њихова је дужност да обезбеде гроб покојнику.
} 
Турчину са још горим намерама (1824: бр. 366), и у семантичкој је инверзији према песмама које су у основи наших анализа. Садржај варијанте из Ошљана се утемељује у духовну вертикалу српског народа.

Посматрано у целини, дакле, овакав склоп чињеница - мотив убиства јунака из заседе док војска/дружина пролази кроз гору, као и мотив молбе умирућег да му се испуни последња жеља (он тражи да га дружина сахрани по одређеном протоколу $\left.{ }^{34}\right)$, у основи је сасвим сведен модел дескрипције јуначких судбина (Павловић 1986: 61), који у скраћеном облику садржи живот јунака, или у крајњој линији последице таквог живота. Тако се, без обзира на краткоћу песме и неразвијеност нарације, причом која је усмерена на јунакову смрт асоцирају његова ранија јуначка дела. Зато у њој и има много елемената херојске етике и поетике ${ }^{35}$ која се налази у основи српске духовне вертикале.

Друга варијанта песме из села Ошљане, која почиње стиховима „Пуче пушка из гору зелену, / Па потреви Раду барјактарку“, састоји се из кратког уводног дела и развијеније молбе умирућег:

Носите ме на царева друма,

Поред пута гробље ископајте,

Уз главу ми копље прибодете,

И на копље цвеће наредете.

Кој да пројде, клупом да си седне,

Ноге да одмори, Ратку да спомене.

И ова песма испевана је из позиције умирућег јунака и по својој садржини иде у групу тестаментарних. Радња је такође фокусирана на начин и место сахрањивања покојника који није умро природном смрћу, „будући да је право на редовну сахрану било ускраћено свим погибалцима [...], посебно убијеним хајдуцима“ (Детелић 2013: 103). ${ }^{36}$ Само сахрањивање, међутим, као и у развијенијој варијанти, односно испуњење јунакове последње жеље, није описано и налази се изван приче - и овакво спрезање је такође део процеса деепизације. Нарав-

\footnotetext{
${ }^{34}$ Тестаментарни детаљи налазе се и у запису песме о смрти Деспота Вука, који је сачињен још половином XVII века (Охмућевић, према Пантић 1964: 59-64).

35 „Колико је ова песничка врста „молбе јунакове“ стари углачани облик епске песме, колико пак мала епска песма која увек поново настаје, може бити спорно. Али то не спречава да се у [њој] могу видети камене основе епског певања из којих је и на којима је лако могуће градити веће епске целине“ (Павловић 1986: 59-60).

${ }^{36}$ Они су, будући да се сматрало да су опасни, сахрањивани тамо где их је смрт задесила (Ђорђевић 1984б: 220-224).
} 
но, будући да је молба заветног карактера и да је упућена саборцима, може се сматрати да је испуњена.

Умирући, поред осталог, јунак моли да га носе „на царева друма“ и да му гроб копају поред пута, што кодира излазак из простора горе, а тражење пута кодира и кретање ка оном свету (Иванов и Топоров 1965: 160). ${ }^{37}$ Затим тражи да се изврше одређене радње с његовим

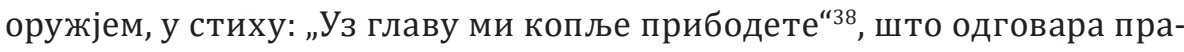
старим начинима сахрањивања јунака с оружјем у различитим временима у прошлости на подручју Балкана, међу Словенима и шире, о чему сведочи велико богатство археолошких налаза (в.: Палавестра 1984: 8-13, 17, 24-25, 34-35, 43, 57, 59, 61-64, 67-68; Janićijević 1986: 196; Јацановић 1998); обичај је забележен и међу ускоцима у 17. веку (Janićijević 1986: 197). А рефлектован је и у чувеној песми о војводи Кајици из Вукове збирке, у стиховима: „Саранише војводу Каицу, / Чело главе копље ударише ${ }^{439}$ (Караџић 1845: бр. 81) ${ }^{40}$, што песму изнова уводи у херојски код и у окружење српске традиције певања уопште. Аналогно се поступа са барјаком: „Пободете му крстата барјака“ (Младеновић 2010), или: „А на срце барјак пободете“ (Симоновић 1988: бр. 104). То упућује и на предмете који су избачени из употребе, чија инверзија положаја на симболичком плану такође сигнификује смрт. Овакав однос према оружју прати се и у старијем слоју бележења: „На коња ми постави пусто копје наопако“, у песми о смрти Деспота Вука (Охмућевић, према: Пантић 1964: 63), где умирући јунак такође моли побратима Митра Јакшића да му испуни последњу жељу, што песму даље повезује с општесрпском традицијом певања с мотивом последње воље умирућег.

Треба такође додати да се у потоњој варијанти, као и у неким другим записима, коњ помиње у функцији заветне жртве:

\footnotetext{
37 Пут покојника семантизује се и овако: „Из сего леса темного вывести и направить на путь на дорогу“ (Иванов и Топоров 1965: 166).

38 У писаним изворима копље се код Срба помиње од 12. века (Шкриванић 1957: 15).

${ }^{39}$ Јиречек сматра да је копље у средњовековној Србији било знак владара (1952: 70;

в. и: Шкриванић 1957: 81-82).

${ }^{40}$ Слично поступа и оболели Марко Краљевић:
}

Разболе се Краљевићу Марко,

Покрај пута друма јуначкога,

Више главе копље ударио,

А за копље Шарца привезао

(Караџић 1845: бр. 54)

Овакав начин уређивања гроба, према мишљењу неких истраживача, „потпуно одговара гробовима бронзаног и гвозденог доба на балканско-карпатском подунавском простору, и то одређеном начину сахрањивања под хумкама - тумулима“ (Јацановић 1998). 
Вржите ми коња на крстачу,

Дан да једе, три да болује.

Ставите му траву чемерику,

Да жалеје Ђуру арамбашу,

(Младеновић 2010: 1975, село Преданча; слично Симоновић, бр. 174)

Мотив отровне траве (чемерике) асоцира на праксу архаичног вида жртвовања коња, познату од давнина на Балкану (в.: Јацановић 1998) и шире, такође међу Словенима (в.: Божић 1956: 87; Палавестра 1984: 8-10, 13, 62; Janićijević 1986: 95-96, 167-170, 172-173, 196-197) ${ }^{41}$. То песнички потврђује и завршница друге варијанте:

„Вежите ми коња за крстачу,

Турете му траву детелину

И дајте му воду леденицу." -

Турише му траву чемерику,

Дан је јео, а два није тео.

Дадоше му воду леденицу,

Дан је пио, а два није пио,

Жалејећи свога господара.

(Ђорђевић 1958: бр. 12, 640-641, Доња Локошница)

На жртвовање коња алудирају не само изгон на пашу, односно присуство пашњака као локуса смрти у традицији Словена (Иванов и Топоров 1974: 67), већ и природа паше, тровање, изгладњивање, жеђ и ледена вода. А будући да коњ, као носилац херојских атрибута, у веровањима има изражену хтонску природу (Кулишић 1998: 250), његова својства погодују посредовању између овог и оног света (в.: Валенцова 1999: 517-520), што је имплицитна жеља умирућег. Коњ као жртвена животиња и водич у доњи свет (Петрухин 1999: 590594) јавља се још у бележењу чувене песме о смрти Деспота Вука, у две њене варијанте, где умирући тражи да му их побратим одведе „у клисуру камениту“, „гди се нигда не находи ни траве, ни бистре воде“ (Охмућевић, према: Пантић 1964: 64), или: „Ђено трава не расте, а не тече хладна вода“ (Богишић 1878: бр. 16) ${ }^{42}$, при чему клисура такође симболизује простор смрти (в.: Иванов и Топоров 1965: 174).

Сам крај краће песме из Ошљана, међутим, фокусиран је на изражену потребу помена, што је стални мотив тестаментарних песама

\footnotetext{
${ }^{41}$ И не само код хришћана, већ и код муслимана, где се говори о сахрањивању из захвалности (в.: Ђорђевић 1958: 154-158).

${ }^{42}$ Симбол јуначког коња овде је, како сматра Соња Петровић, „стопљен с мотивом старања о души - као да се коњ жртвује“ за њен спас (Петровић 2005: 14-15).
} 
у целини којим су обележене и неке од регионалних варијаната из истог тематско-сижејног круга:

Пободете му крстата барјака,

Вржете му коња за јелу зелену,

Дан да једе, два да жалеје,

Коњ зеленко повикује

Те си Ђуру помењује.

(Младеновић 2010: забележено 1976, село Пржоње)

Или:

Стар да прође, да с воде напије,

Млад да прође, цвеће да набере,

Да спомене Ранчу буљубашу.

(Манојловић 1953: бр. 187; идентични стихови: Симоновић

1988: бр. 105)

Али постоје и завршеци који су фокусирани на обнову живота, као у песми која је, према сведочанству бележиоца, певана на биљани петак:

Са сабљама гроба ископајте,

Више главе јелу посадите,

За јелу ми коња привежите,

На срце ми ружу посадите -

Ко је јунак, нека коња јаше,

Ко је кицош, ружом нек се кити,

Ко је жедан, воде нека пије.

(Грбић 1909: 55-56, околина Бољевца)

И стога је могуће да она „коментарише“ иницијацијску смрт и васкрсење у другачијем појавном виду, али ова тема превазилази оквире рада.

Померање према оптимистичном односу према животу и, наравно, жанровском окружењу, евидентно је и у другим аналогним варијантама:

Више главе цвеће посадите,

Крај ноге ми извор извадите,

Када дођу Жупљанке девојке,

Нека пију извор воду ладну,

Нека беру цвеће свакојако!

(Симчевић 2014: бр. 1100)

И ту се види способност одређене фолклорне матрице да се динамички отвара за нова значење, тако да се на смрт гледа као на кружни 
циклус непрекидног трајања живота у различитим појавним облицима. При томе коначног нестајања и нема, а надвладавање смрти враћа на прастару митску матрицу којом се слави живот.

Може се, дакле, рећи да су анализиране песме из Белог Тимока, и њима одговарајуће регионалне варијанте, упркос томе што су захваћене одређеним процесима сажимања и дехероизације, сачувале неке основне карактеристике наше јуначке епике у њеним различитим менама и фазама. И, сходно томе, песме из Ошљана, као и остале представљене варијанте, с њом деле јединствени поглед на свет који је укорењен у српском народу.

\section{Библиографија}

Богишић, Валтазар (1878). Народне пјесме из старијих, највише приморских заnиса, књ. 1. Гласник Српског ученог друштва, Одељење 2, књ. 10. Београд: Државна штампарија.

Валенцова, Марина М. (1999). Кобила. Славянские древности. Этнолинвистический словарь (в пяти томах), том II. Ред. Н. И. Толстой. Москва: Российская академия наук, Институт славяноведения, 517-520.

Васић, Павле (1979). Српска народна ношња у средњем веку. Гласник Етнографског музеја 43, 23-56.

Валенцова, Марина М. и Людмила Н. Виноградова (2001). Бунар. Словенска митологија. Ур. С. М. Толстој и Љ. Раденковић. Београд: Zepter Book World, 58-59.

Грбић, Саватије (1909). Народни обичаји из среза Бољевачког. Српски етнографски зборник 14. Београд: Српска академија наука и уметности.

Грбић, Саватије (1966). Лепа тицо, бела Радо (избор народних песама). Развитак 1: 49-52.

Детелић, Мирјана (1992). Митски простор и епика. Београд: Српска академија неука и уметности.

Детелић, Мирјана (2008). Формулативност и усмена епска формула: Атрибути бело и јуначко у српској десетерачкој епици. Српско усмено стваралаштво, ур. С. Самарџија. Београд: Институт за књижевност, 119-145.

Детелић, Мирјана (2013а). Епски бунари. Aquatica. Књижевност, култура. Ур. М. Детелић и Л. Делић. Београд: Балканолошки институт САНУ, 213-230.

Детелић, Мирјана (2013б). Гроб у гори. Биље у традиционалној култури Срба (приручник фолклорне ботанике). Ур. З. Карановић и Ј. Јокић. Нови Сад: Филозофски факултет, 99-118.

Ђорђевић, Драгутин (1958). Живот и обичаји народни у Лесковачкој Морави. Српски етнографски зборник LXX. Београд: САНУ.

Ђорђевић, Драгутин и Момчило Златановић (1990). Народне песме из Лесковачке области. Српски етнографски зборник 95. Српске народне умотворине 4. Београд: САНУ. 
Ђорђевић, Тихомир (1958). Коњ. Природа у веровању српског народа. Прва књига. Српски етнографски зборник LXXI. Живот и обичаји народни 32. Београд: САНУ, 134-163.

Ђорђевић, Тихомир (1984а). Коњ и оружје као знаци положаја и старешинства. Наш народни живот 1. Ур. Н. Љубинковић. Београд: Просвета, 103-108.

Ђорђевић, Тихомир (1984б). Неколики самртни обичаји у Јужних Словена. Наш народни живот 1. Ур. Н. Љубинковић, Београд: Просвета: 124-246.

Ђурић, Томислав (прир.) (2006). Српска песмарица. Темишвар: Савез Срба у Румунији. Преузето са: http://etnoselo.blogspot.com/2012/02/blogpost_6247.html Приступљено: 1.5. 2020.

Иванов, Вячеслав Вс. и Владимир Н. Топоров (1965). Славянские языковые моделирующие семиотические системы. Москва: „Наука“.

Иванов, Вячеслав Вс. и Владимир Н. Топоров (1974). Исследования в области славянских древностей: Лексические и фразеологические вопросы реконструкции текстов. Москва: „Наука“.

Јацановић, Драган (1998). Српска народна епика као извор археолошке информације. Гласник Српског археолошког друштва 15/14, 299-313. Преузето са: https://www.rastko.rs/arheologija/delo/10968 Приступљено: 1. 5. 2020.

Јиречек, Константин (1952). Историја Срба І. Прев. Ј. Радонић. Београд: Научна књига.

Карановић, Зоја (2006). Српске и бугарске народне баладе о смрћу растављеним љубавницима. Научни трудове. Филология 41/1, Пловдив, 2003. Пловдив: Универзитетско издателство „Паисий Хилендарски“, 179-191.

Карановић, Зоја (2009). Ружа у српској традиционалној култури и народној поезији. Синхронијско и дијахронијско изучавање врста у српској књижевности. Ур. 3. Карановић и И. Живанчевић-Секеруш. Нови Сад: Филозофски факултет, 19-48.

Караџић, Вук Ст. (1841). Српске народне пјесме, књ. I. Беч: Штампарија јерменскога манастира.

Караџић, Вук Ст. (1845/1988). Српске народне пјесме, књ. II. Сабрана дела Вука Карацића, књ. 5. Прир. Р. Пешић. Београд: Просвета.

Караџић, Вук Ст. (1852). Српски рјечник истумачен њемачкијем и латинскијем ријечима. Беч: Штампарија јерменскога манастира.

Крњевић, Хатиџа (1986). Лирски источници. Београд, Приштина: БИГЗ, „Јединство“.

Костић, Лазо (1960): О заставама код Срба: историска разматрања. Минхен: Л. Костић.

Кулушић, Шпиро (1998). Коњ. Српски митолошки речник. Ур. Ш. Кулишић, П. Ж. Петровић, Н. Пантелић. Београд: Етнографски институт САНУ: 250-251.

Манојловић, Коста (1953). Народне мелодије из источне Србије. Београд: Научна књига.

Мелетинский, Е. М (1986). Введение в историческую поэтику эпоса и романа. Москва: Академия наук СССР.

Милошевић-Ђорђевић, Нада (1990). Косовска епика. Београд: Завод за уџбенике. 
Младеновић, Мирослав (2010). Хајдучке и остале песме из власотиначкога краја. Преузето са: https://www.mycity-military.com/Ostalo-5/Hajducke-iostale-pesme-iz-vlasotinackog-kraja.html Приступљено: 1. 5. 2020.

Палавестра, Александар (1984). Кнежевски гробови старијег гвозденог доба на централном Балкану. Београд: Балканолошки институт САНУ.

Пантић, Мирослав (1964). Народне песме у записима XV-XVIII века. Београд: Просвета.

Петровић, Соња (2005). Старање о души. Тестамент Милоша Белмужевића и епски модели о последњој вољи јунака. Прилози за књижевност, језик, историју и фолклор 71, 3-22.

Петрухин, Владимир Я. (1999). Конь. Славянские древности. Этнолинвистический словарь (в пяти томах), том II. Ред. Н. И. Толстой. Москва: Российская академия наук, Институт славяноведения, 590-594.

Пешикан-Љуштановић, Љиљана (2014). Кућа необична. Зборник Матице српске за књижевност и језик 62/1: 7-25.

Првуловић, Борислав, Светислав Првановић и Владимир Јеремић (1962). Кој је жедан воду нека пије. Развитак 3, 40-41.

Симоновић, Драгољуб (1988). Народне песме из Источне и Јужне Србије. Београд: Филозофски факултет.

Симчевић, Велибор (2014). Народна лирика Жупе александровачке (савремена теренска истраживања и наслеђена грађа). Докторска дисертација. Универзитет у Београду, Филолошки факултет. Преузето са: http://nardus.mpn.gov. rs/bitstream/handle/123456789/4273/Disertacija22.pdf Приступљено: 1. 5. 2020.

Станковић, Живојин (1951). Народне песме у Крајини. Београд: САНУ.

Чајкановић, Веселин (1994а). Студије из српске религије и фолклора 1910-1924. Сабрана дела из српске религије и митологије, књ. 4. Прир. В. Ђурић. Београд: Српска књижевна задруга и др.

Чајкановић, Веселин (1994б). Студије из српске религије и фолклора 1925-1942. Сабрана дела из српске религије и митологије, књ. 4. Прир. В. Ђурић. Београд: Српска књижевна задруга и др.

Чајкановић, Веселин (1994в). Речник српских народних веровања о биљкама. Сабрана дела из српске религије и митологије, књ. 4. Прир. В. Ђурић. Београд: Српска књижевна задруга и др.

Шкриванић, Гавро (1957). Оружје у средњовековној Србији, Босни и Дуборовнику. Београд: САНУ.

Janićijević, Jovan (1986). U znaku Moloha. Beograd: Vajat.

Lič, Edmund (1983). Kultura i komunikacija. Prev. B. Hlebec. Beograd: Prosveta.

Pavlović, Miodrag (1986). Uz smederevsku bugaršticu. Obredno i govorno delo. Beograd, Priština: Prosveta, „Jedinstvo“.

Schmaus, Alois (1971). Vrsta i stil u narodnom pesništvu. Usmena književnost. Prir. M. Bošković-Stulli, Zagreb: Školska knjiga, 59-63.

Schmaus, Alois (1971a). Iz Studija o krajinskoj epici. Usmena književnost. Prir. M. Bošković-Stulli, Zagreb: Školska knjiga, 219-248. 


\section{ПРИЛОГ}

Ћиша пада, путници путују.

Сви јунаци барјаци савише,

Гојко јунак барјак не савија.

„Сави”, Гојко, барјак да не ћисне!“-

„Нека ћисне, пуст да га остане!

Имао сам девет мила брата,

Сви су девет под њег' пођинули,

И мен' пише, и ја да пођинем.“

Таман Гојко тој изрече,

Пуче пушка из гору зелену,

Па погоди Гојко барјактара.

Мртва глава, језик проговара:

„Над главом ми бунар ископајте,

Око бунар цвеће посадете,

Око цвеће клупе наместете.

Кад се врати војска са Косово

Ко је жедан, воду да си пије,

Ко је млађан, цвеће да се кити,

Куј је рањен, клупе да си седне.“

Таман Гојко то изрече,

Ал' ето ти војска од Косово.

Ко је жедан, воду пио,

Ко је млађан, цвеће се китио,

Куј је рањен, клупе одморио.

(казивала Љубица Пујић, Ошљане)

Пуче пушка из гору зелену,

Па потреви Раду барјактарку.

Мртва глава, језик проговара:

„Носите ме на царева друма,

Поред пута гробље ископајте,

Уз главу ми копље прибодете,

И на копље цвеће наредете.

Кој да пројде, клупом да си седне,

Ноге да одмори, Ратку да спомене.“

(казивала Љубица Ђорђевић, Ошљане) 


\section{Two Serbian Songs about a Hero's Burial in the Woods from the Region of Beli Timok (Eastern and Southeastern Serbia)}

\section{Zoja Karanović}

\section{Summary}

The paper discusses valuable records of two Serbian folk songs which the Author, together with Vesna Djukić, noted down in the village of Ošljane in the Region of Beli Timok, in 1997. The song is related to the similar thematic-motivic and content variants gathered in the broader area of Eastern and Southeastern Serbia, where they can be traced during the $20^{\text {th }}$ century. There are melodic notations of the song as well, and melodic records posted on the Internet demonstrate its popularity. Significant clues of the song's life point to the once great wealth of the Serbian oral poetic tradition in the examined area. They also testify to its genre and poetic dynamic and flexibility, and particularly to the fact that it is intrinsic to the Serbian folk poetry in the whole.

Keywords: Serbian folk heroic songs, The Region of Beli Timok (Eastern and Southeastern Serbia), death in the woods, grave in the woods, field records, process of deheroization, decreasing of epic intensity

Проф. др Зоја Карановић

Професор Универзитета у Новом Саду у пензији Е-пошта: zojanko@stcable.net
Примљено: 26. 5. 2020.

Прихваћено: 15. 6. 2020. 